\title{
HISTORICAL AND PRESENT DAY PERSPECTIVES ON FISH POPULATIONS \\ IN THE ROCK CREEK DRAINAGE IN \\ WEST CENTRAL MONTANA, 1971-2004
}

By: Rodney K. Berg Fisheries Biologist

Montana Fish, Wildlife \& Parks

Federal Aid

Project Númber: F-113-R1 F-113-R2

Project Title: Statewide Fisheries Management

Job Title: Rock Creek Drainage Fisheries Management

Date: May, 2004 


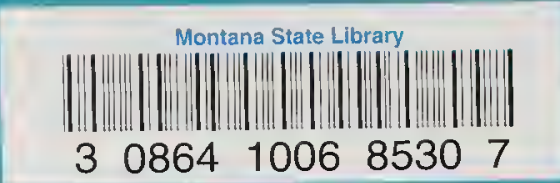




\begin{abstract}
Rock Creek has historically provided one of the most important blue ribbon trout fisheries in Montana. Rainbow trout provided the bulk of the fishery until recent years. Chronic low flows, elevated water temperature and whirling disease have reduced rainbow trout density by over 80 percent since 1993, while brown trout have increased substantially in density. Westslope cutthroat and bull trout densities have also declined significantly since peaks observed in the early 1980's. Historic estimates for a 33 year period of record, 1971 through 2004, are presented. Summer recruitment and winter mortality of rainbow trout and the status of whirling disease in the drainage are discussed.

Bull trout redd counts conducted from 1993 to 2003 in six critical spawning tributaries peaked in 1998 and have generally declined since then. Reduced redd counts appear to be correlated with reduced stream flow in the spawning tributaries. Management recommendations for an adfluvial bull trout population in East Fork Rock Creek Reservoir, imperiled by poor spawning success and loss of fish to an irrigation diversion, are discussed.
\end{abstract}





\section{INTRODUCTION}

A basic inventory is essential in formulating management plans for maintaining and utilizing a fishery. Seldom is this information complete for an entire area or drainage. Streams and lakes in the Rock Creek drainage in west central Montana support one of the most significant and heavily utilized sport fisheries in the region and state.

Increasing human inhabitation and encroachment on lands adjacent to streams, and increasing fishing and recreational use of streams in the Rock Creek drainage provide increasing challenges to effective management of the blue ribbon trout fishery in this drainage.

Environmental changes in the 1990's, including low stream flows associated with chronic drought and the introduction and spread of whirling disease, have also increased the need for better information to meet management challenges.

\section{DESCRIPTION OF STUDY AREA}

The Rock Creek drainage lies in west central Montana, and is a principal tributary of the Clark Fork River. It enters the Clark Fork River about 25 miles upstream of Missoula, Montana.

\section{TECHNIQUES}

\section{Electrofishing}

Fish were sampled in streams in the drainage using direct current electrofishing. Boomsuspended or mobile electrofishing apparatus carried in water craft were used on larger streams. Backpack electrofishing systems were used on smaller streams.

\section{Gill Nets}

Fish were sampled in lakes in the drainage using standard "Montana" experimental floating and sinking nylon or monofilament gill nets $6 \times 125 \mathrm{ft}$. with graduated mesh size from $3 / 4$ to 2 inches square measure. Overnight stationary sets with these nets generally produced good catches of a wide variety of fish species. The nets were equally distributed around the entire perimeter of each lake to produce a representative catch. The locations of each gill net set were marked on USGS topographic maps. In addition, GPS coordinates for each gill net set were recorded for future reference.

\section{Fish Sample Processing and Tagging}

Sampled fish were measured to the nearest millimeter in total length, and weighed to the nearest 10 grams. Sex and spawning condition (gravid, ripe or spawned) were recorded for fish captured during their spawning period.

Fish population estimates were made using the log likelihood method incorporated in Version 4 of the Montana Fish, Wildlife and Parks program. Captured fish were marked with fin clips or punches and recaptured after marked fish redistributed into the population for one to two weeks. 
Digitized by the Internet Archive in 2017 with funding from Montana State Library 


\section{FINDINGS, RESULTS AND DISCUSSION}

\section{Mainstem Rock Creek Fish Populations}

Rock Creek has historically provided one of the most important blue ribbon trout fisheries in Montana. Angler interest and fishing pressure has steadily increased over the past half century.

The highest angling interest and fishing pressure has always occurred on the lower 40 to 50 miles of the mainstem of Rock Creek. This reach of stream is floatable by water craft during high water. In addition, the famous salmon fly hatch occurs each year in this area during late spring to early summer.

For these reasons, trout populations have been estimated by electrofishing in Rock Creek for a longer period of record than in any other stream in west central Montana. Trout population estimates were initiated by then Montana Fish and Game biologist, Ron Marcoux, in September, 1971, in the Fish and Game Section, 13.8 miles upstream from the mouth. The following fall, Marcoux initiated estimates in the Hogback Section, 30.6 miles upstream from the mouth.

During this report period all past trout population estimates in these sections were standardized to a common estimator, the log likelihood estimator, incorporated in Version 4 of the Montana Fish, Wildlife and Parks fish population estimate program. All data were keypunched and analyzed by a common observer to eliminate estimate variance due to a variety of past estimator methods and observers.

Since the inception of electrofishing in 1971, 18 rainbow trout population estimates have been made in the Hogback Section and 24 have been made in the Fish and Game Section (Tables 1 and 2). This includes the most recent estimates which were made in each section in Spring, 2004. Due to lower densities, brown, westslope cutthroat and bull trout have been successfully estimated on fewer occasions.

Findings reveal rainbow trout have provided the bulk of the sport fishery in Rock Creek until recent years. Hatchery rainbow trout were planted in Rock Creek through 1972. Following suspension of hatchery supplementation, wild and total rainbow trout densities probably increased significantly in Rock Creek. Even though baseline data prior to 1972 are lacking for Rock Creek, monitoring of other streams in Montana consistently showed significant increases in rainbow trout densities following suspension of hatchery planting.

Although trout population estimates obtained on Rock creek in the 1970's meet minimum acceptable criteria, in terms of numbers of recaptured fish required to project a valid estimate, the 1970 's data should probably be viewed with skepticism due to primitive electrofishing gear employed during that time period. Electrofishing currents used in the 1970's included alternating and pulsed direct current outputs, which presently are known to cause fish injury, movement and mortality. If mortality or movement of marked fish occurs between mark and recapture runs, assumptions for a valid estimate are violated, and resulting estimates are invalid and inflated. It appears several 1970's estimates in Rock Creek are invalid and inflated due to this factor. 



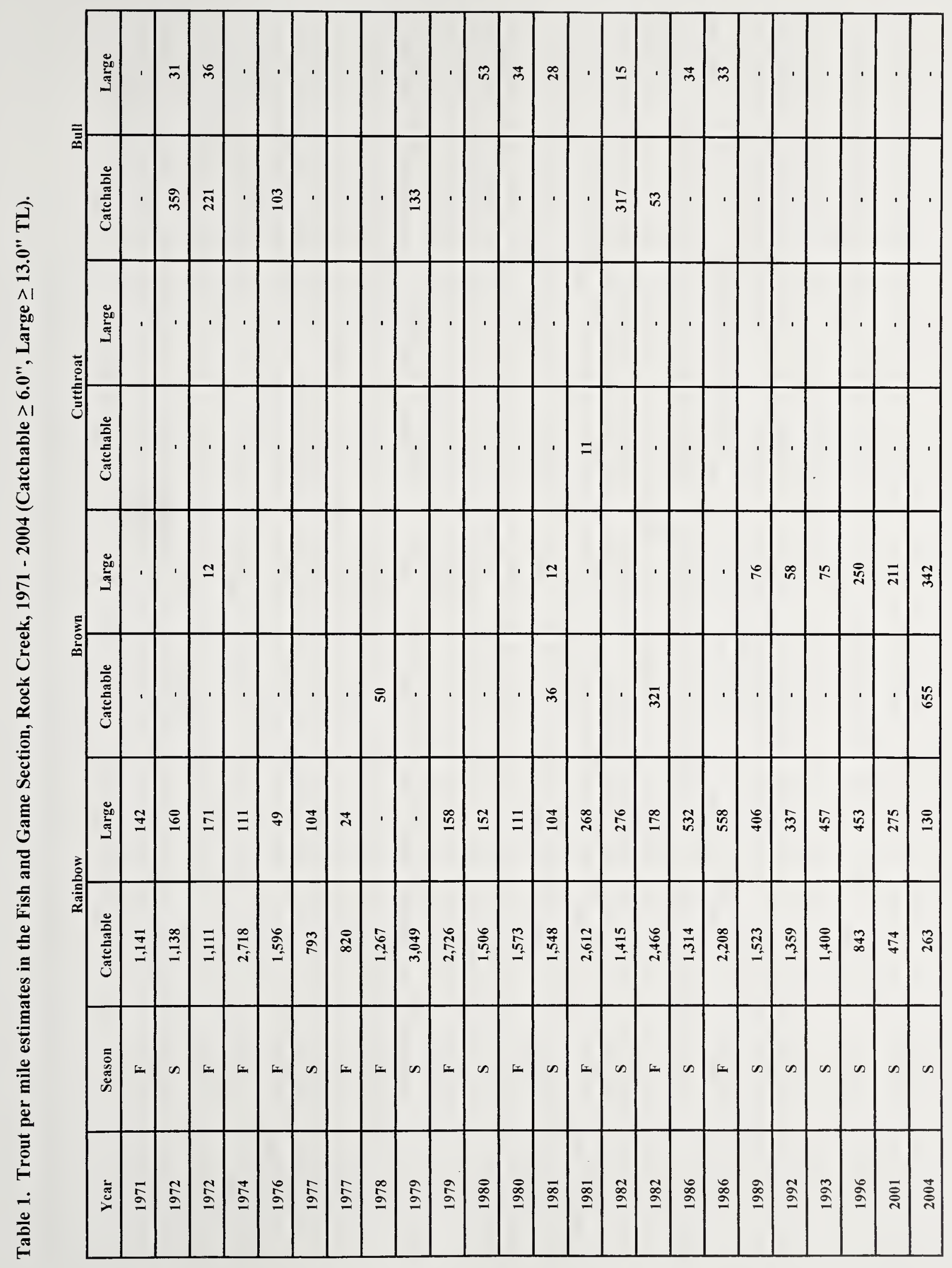





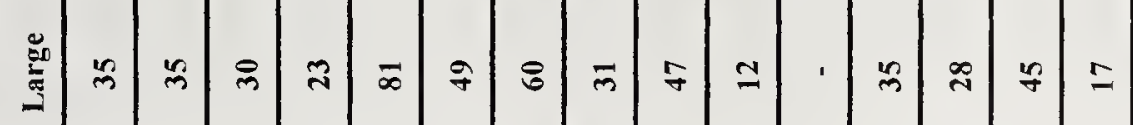

三

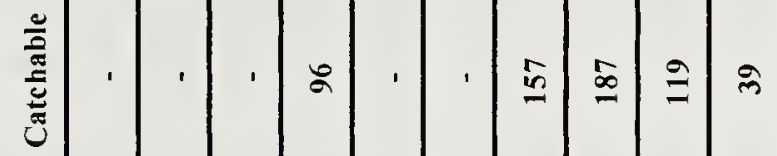
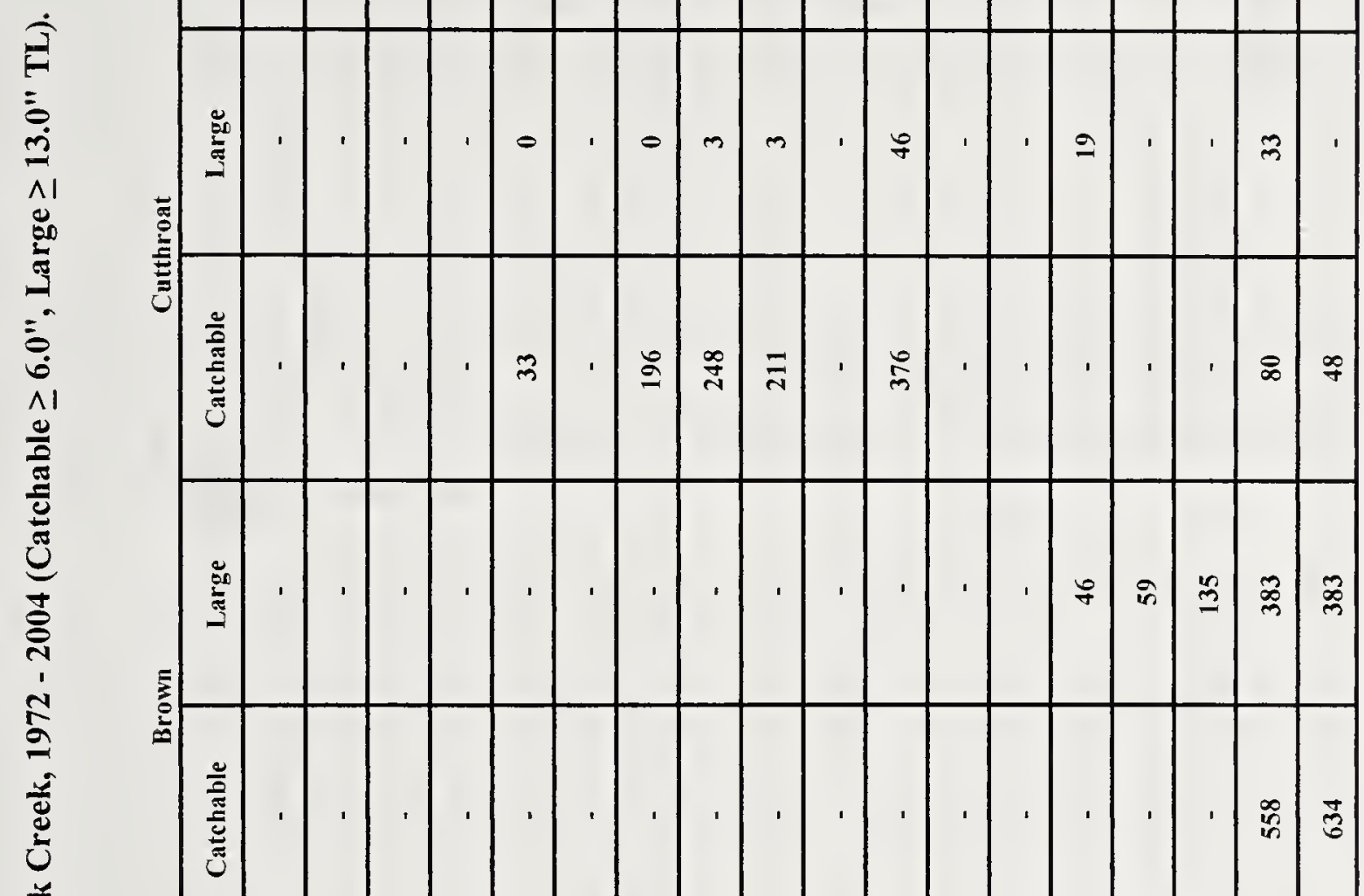

(⿸\zh14⿰⿺乚一匕

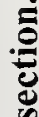

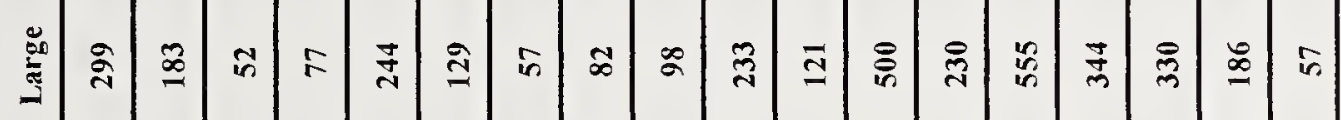

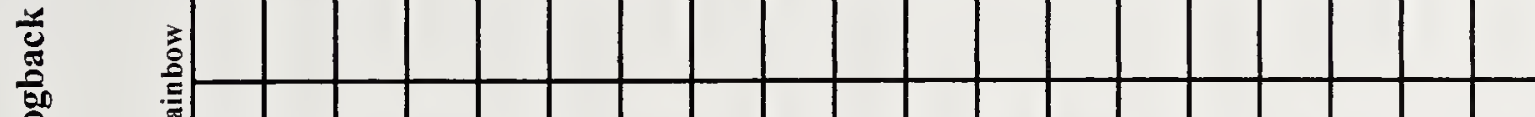

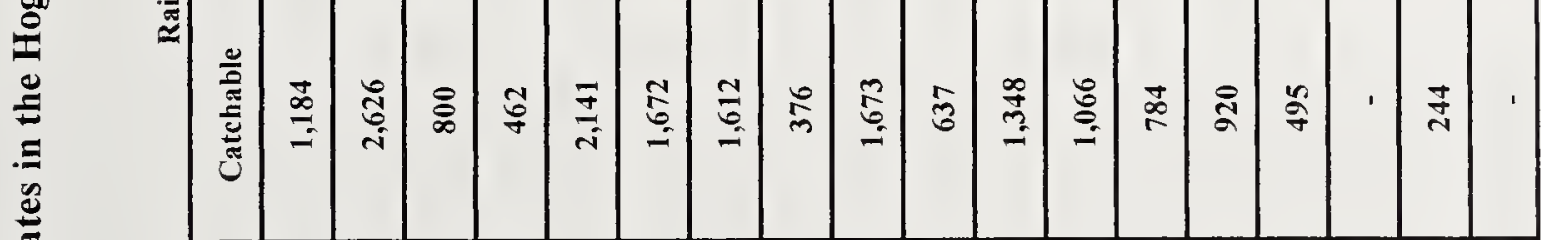

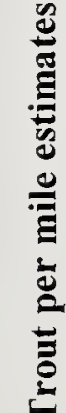

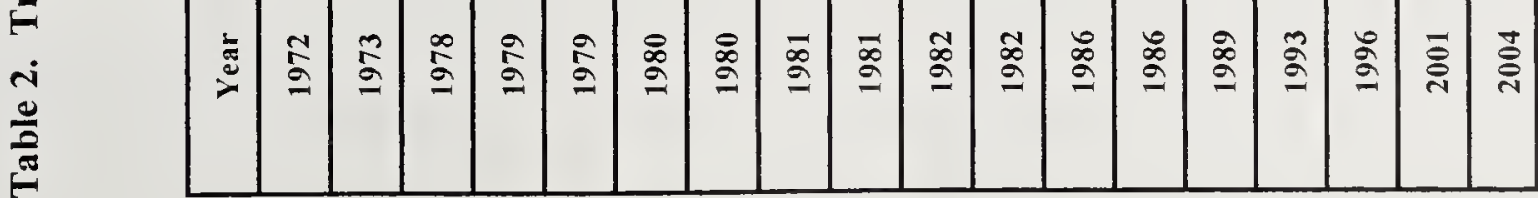



By the 1980's electrofishing methods began to employ continuous direct current reducing electrofishing injuries, mortality and movement. For this reason, trout population discussions in this report are confined to estimates obtained after 1980.

\section{Rainbow Trout}

Most historic and all recent trout population estimates in Rock Creek have been made in the spring. Between 1980 and 1993, catchable rainbow trout spring densities in the Fish and Game Section of Rock Creek were remarkably consistent varying from 1,314 to 1,548 fish per mile (Figure 1). Between 1993 and 1996 and continuing through 2004, catchable rainbow trout declined precipitously in the Fish and Game Section. Catchable rainbow declined from an average density of about 1,500 fish per mile between 1980 and 1993 to 263 fish per mile in 2004, or by 82 percent.

In the Hogback Section, catchable rainbow trout spring densities varied from 1,672 to 376 fish per mile, averaging about 1,000 fish per mile, between 1980 and 1993 (Figure 2). Catchable rainbow declined from a recent peak spring density of 1,066 fish per mile in 1986 to 115 fish per mile in 2004, or by 89 percent. Large rainbow declined from 555 fish per mile in 1989 to 57 fish per mile in 2004, or, also, by 89 percent. Explanations for these dramatic declines will be presented later in this report.

Since 1980, spring and fall estimates for rainbow trout were obtained in four different years, 1980, 1981, 1982 and 1986, in the Fish and Game Section. In each of these four years, catchable rainbow trout population densities increased between spring and fall. Density increases ranged form 4 percent in 1980 to 68 percent in 1986. In healthy trout populations which are not over exploited by angling, catchable trout population increases should be expected between spring and fall due to fish growth during this time period. This is often referred to as summer recruitment.

Large rainbow trout, greater than or equal to 13 inches in total length, increased between spring and fall by 158 percent in 1981 and 5 percent in 1986 but decreased by 27 percent in 1980 and 36 percent in 1982. This indicates large rainbow were over exploited or moved from the section between spring and fall in 1980 and 1982.

Also, since 1980, spring and fall estimates for rainbow trout were obtained in four different years, 1980, 1981, 1982 and 1986, in the Hogback Section. In 1980, catchable and large rainbow densities decreased between spring and fall by 4 and 56 percent, respectively. In 1981, catchable and large rainbow increased between spring and fall by 345 and 20 percent. In 1982, catchable rainbow increased by 112 percent between spring and fall while large rainbow decreased by 48 percent. In 1986, catchable and large rainbow decreased by 26 and 54 percent, respectively, between spring and fall. These findings indicate catchable and large rainbow were often over exploited or moved from the Hogback Section between spring and fall.

In all trout populations, some decrease in catchable and large trout densities is expected between fall and spring due to winter mortality. On two occasions, between fall and spring, 198081 and 1981-82, estimates are available to measure winter trout mortality on Rock Creek. 



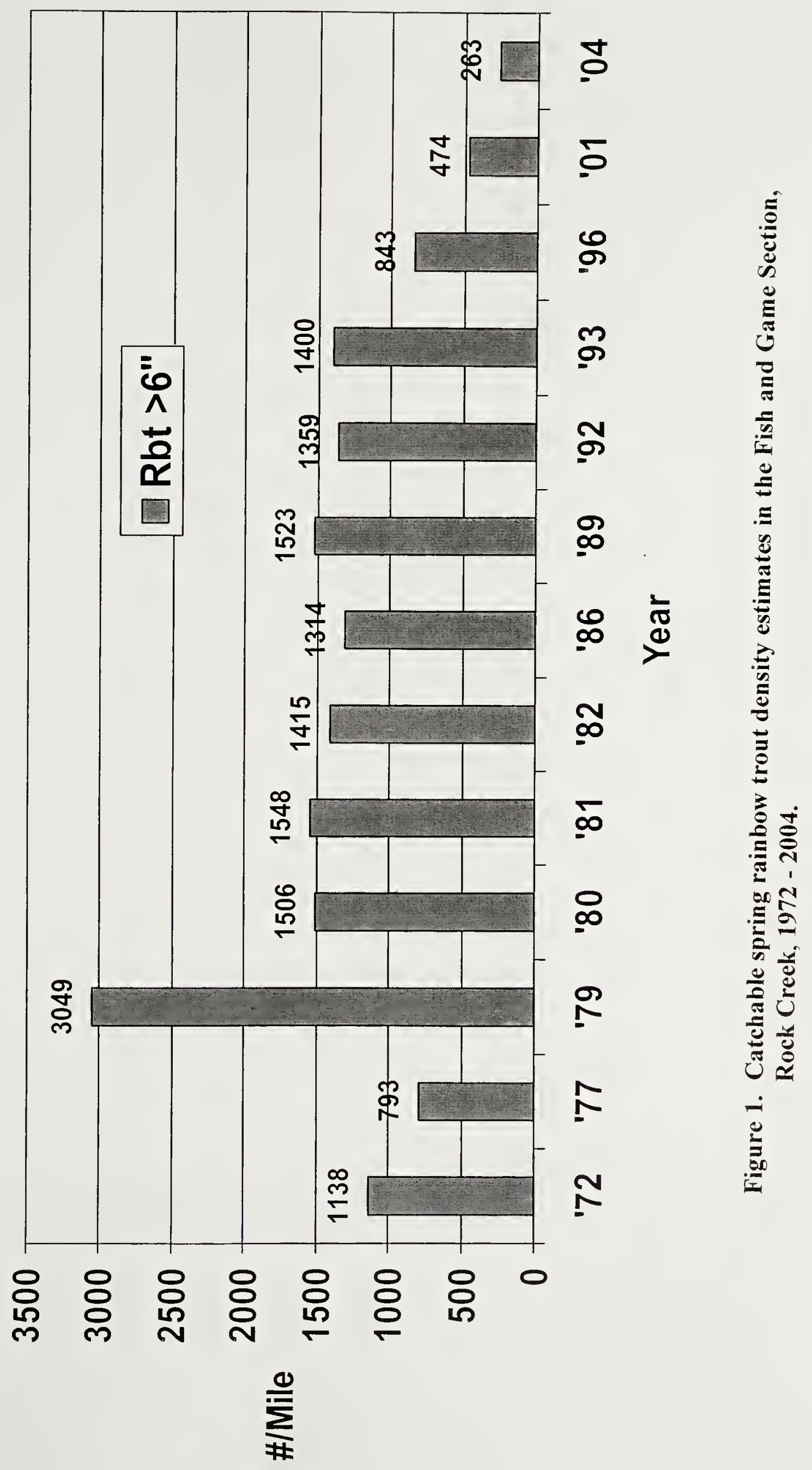





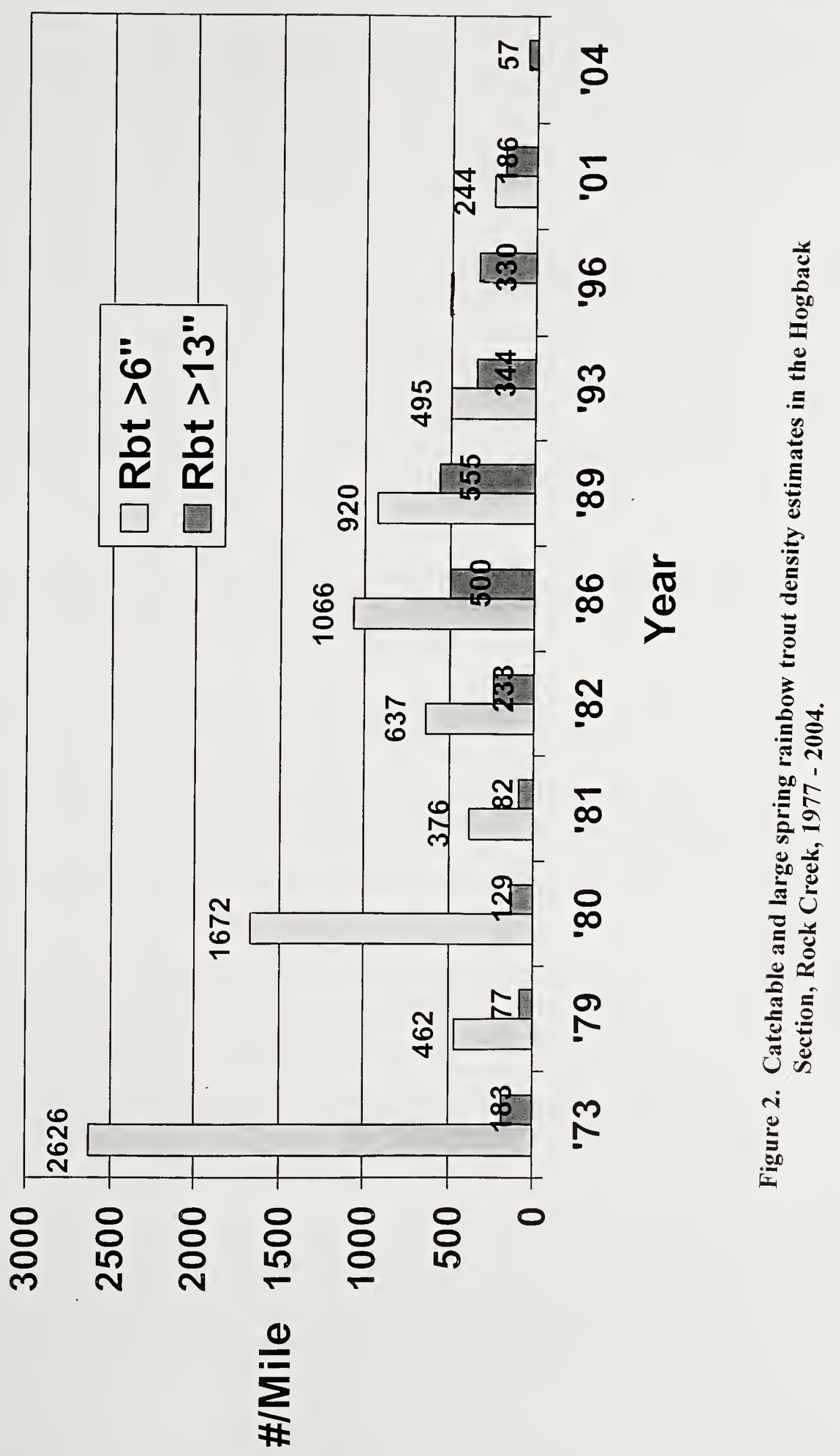



Findings reveal catchable rainbow trout winter mortality of 2 percent in 1980-81 and 46 percent in 1981-82 in the Fish and Game Section. In the Hogback Section catchable rainbow trout winter mortality amounted to 77 percent in 1980-81 and 62 percent in 1981-82. Large rainbow densities decreased between fall and spring by 6 percent in 1980-81 but increased by 3 percent in 1981-82 in the Fish and Game Section, indicating winter mortality was more than offset by movement of spring spawning rainbows into the section. Large rainbow trout densities increased between fall and spring by 44 percent in 1980-81 and 138 percent in 1981-82 in the Hogback Section indicating a more significant movement of spawning fish into this section.

Implications of these observations with regard to validity of spring estimates for rainbow in Rock Creek are significant. Since 1989, or for the past 15 years, only spring estimates have been made on Rock Creek due to low water navigability difficulties and increased angler conflicts (i.e.: increased fishing pressure) in the fall. Since fall estimates seem to be precluded for these reasons and since rainbow trout, a spring spawner, have decreased significantly in density while brown trout, a fall spawner, have increased, spring estimates should be continued. However, marking and recapture electrofishing runs should be standardized to the same time each spring to minimize estimate error and variability attributable to rainbow trout spring movement.

\section{Brown Trout}

In contrast to declining densities of rainbow trout, brown trout have increased in density in the Hogback and Fish and Game Sections. (Figure 3). Successful estimates of large brown trout have been made since 1989 in both the Hogback and Fish and Game Sections.

In the Hogback Section, large brown trout, greater than or equal to 13 inches in total length, increased from 46 fish per mile in 1989 to 383 fish per mile in 2004, or by 733 percent. In the Fish and Game Section, large brown trout increased from 76 to 342 fish per mile, or by 350 percent, between 1989 and 2004. By 2001 and 2004, large brown trout outnumbered large rainbow trout in the Hogback and Fish and Game Sections, respectively. Recent catchable brown trout estimates could not be made until 2001 in the Hogback Section and 2004 in the Fish and Game Section. In 2004, 634 catchable brown trout were observed in the Hogback Section compared to 655 in the Fish and Game Section.

Total large trout density has essentially remained stable in the Hogback and Fish and Game Sections due to replacement of large rainbow trout by large brown trout (Figure 3). However, total catchable trout densities have declined from an average of about 1,000 fish per mile between 1980 and 1993 to 634 fish per mile in 2004, or by 37 percent, in the Hogback Section (Table 2). In the Fish and Game Section, total catchable trout densities declined from an average of about 1,500 fish per mile between 1980 and 1993 to 918 fish per mile in 2004, or by 39 percent (Table 1).

Replacements of large rainbow trout by large brown trout indicates adult brown trout have pioneered vacant space left due to declining densities of large rainbow trout in both sections. Catchable brown trout, estimable in 2001 and 2004 in the Hogback Section and in 2004 in the Fish and Game Section, will probably continue to increase in density. Earlier pioneering in the Hogback Section, 30.6 miles upstream from the mouth, than in the Fish and Game Section, 13.8 



\section{HOGBACK SECTION}

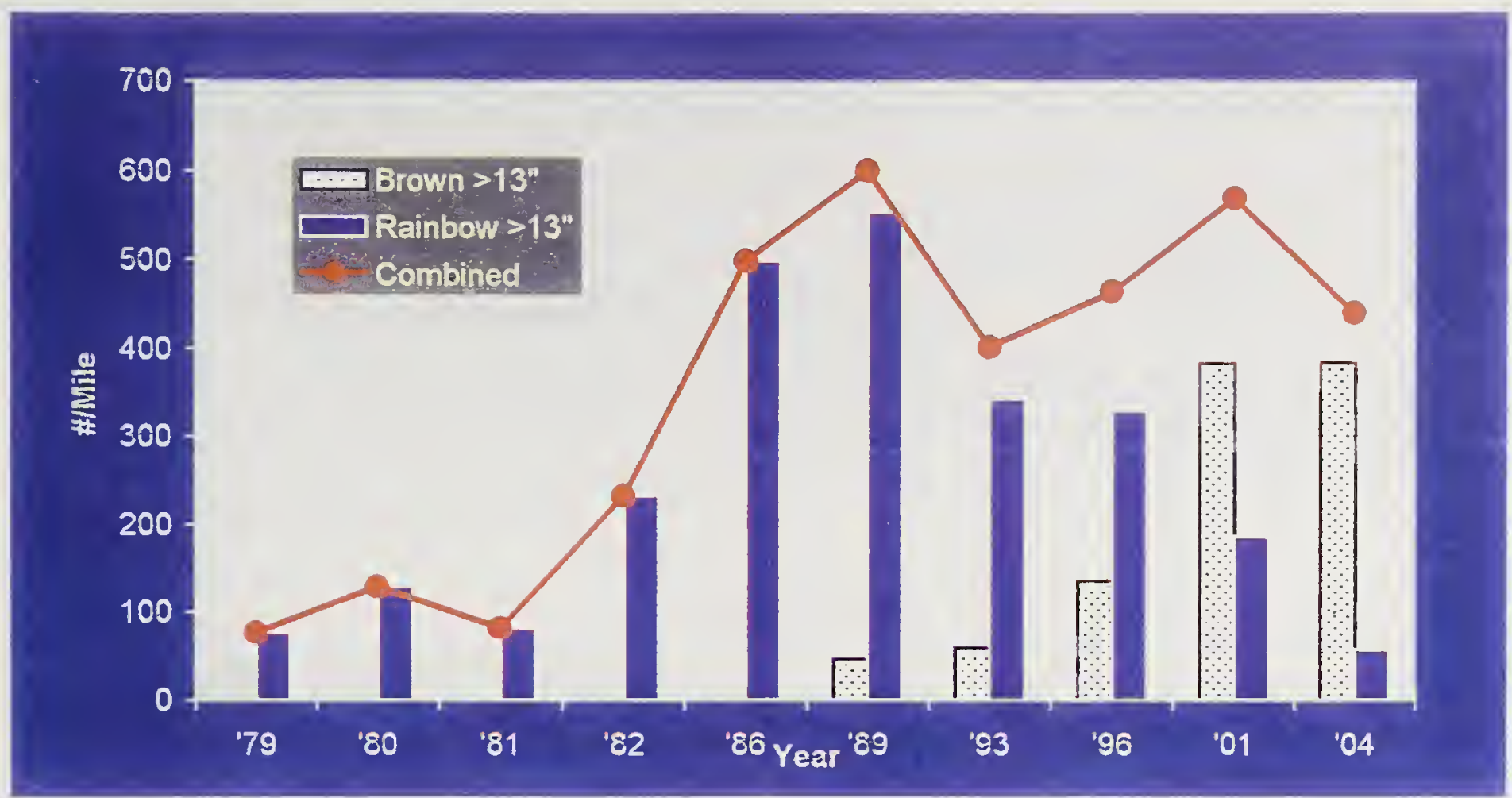

\section{FISH AND GAME SECTION}

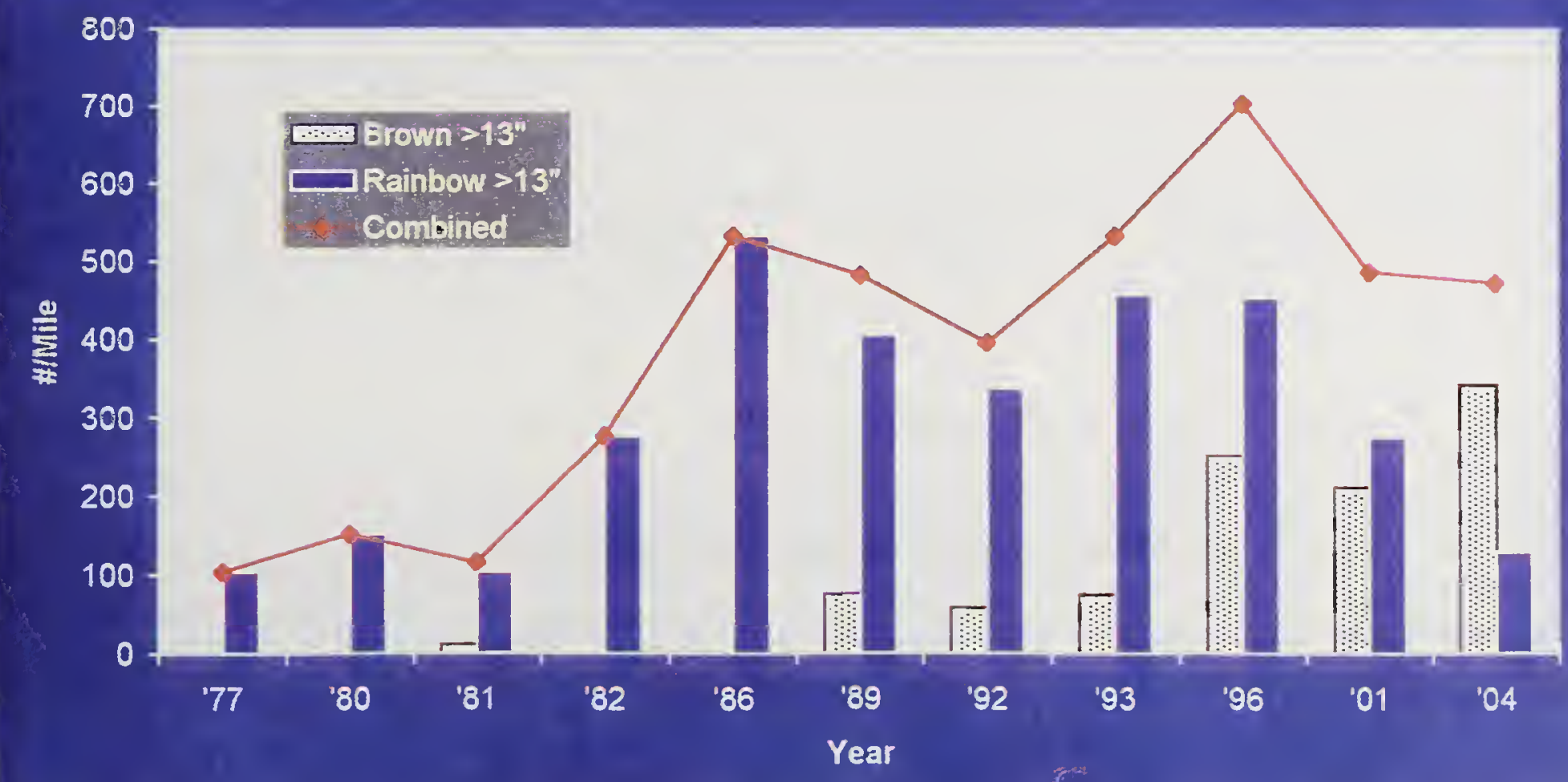

Figure 3. Large raimbow and brown trout sprimg density estimates in the Hogback and Fish and Game Sections, Rock Creek, 1977 - 2004. 


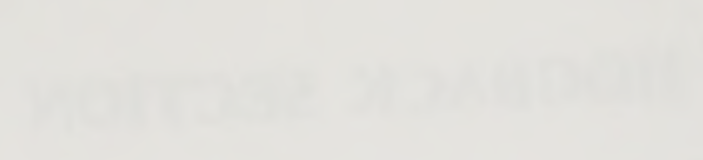


miles upstream from the mouth, indicates pioneering of brown trout is probably occurring due to downstream rather than upstream movement of fish.

\section{Westslope Cutthroat Trout}

Westslope cutthroat trout are a species of special concern in Montana due to declining distribution and numbers in some parts of their range. In Rock Creek catchable westslope trout were not found in estimable numbers until after restrictive fishing regulations were implemented in May, 1979. Following implementation of restrictive regulations, which, in part, reduced the daily limit of trout from ten fish to three fish, westslope cutthroat trout estimates were obtained for the first and only time in fall, 1981, in the Fish and Game Section at a density of 11 catchable fish per mile (Table 1). In the Hogback Section, westslope cutthroat estimates have been obtained sporadically, in seven different years between 1979 and 2004 (Table 2). Catchable cutthroat densities in this section have ranged from 33 fish per mile in fall, 1979, to 376 fish per mile in fall, 1982. Explanations for the increase in cutthroat densities after 1979 and their demise after 1982 will be presented later in this report.

\section{$\underline{\text { Bull Trout }}$}

Bull trout were generally found in estimable numbers from 1980 to 1986 in the Fish and Game Section and from 1980 to 1993 in the Hogback Section (Tables 1 and 2). Estimates of bull trout densities obtained prior to 1980, may not be valid due to primitive electrofishing gear which probably caused fish movement and mortality, violating assumptions of a valid estimate.

Explanations for the decline in bull trout densities in Rock Creek will be presented later in this report. The highest densities of catchable bull trout since 1980 were 317 fish per mile in spring, 1982, in the Fish and Game Section and 187 fish per mile in spring, 1981, in the Hogback Section.

\section{Stream Flow}

Stream flow has been monitored in Rock Creek near its confluence with the Clark Fork River for a 31 year period of record from October 1, 1972, to September 30, 2003, by the U.S. Geological Survey (USGS). USGS data indicate chronic low mean daily stream flows of less than 90 cubic ft. per sec. (cfs) have been observed in 10 of the past 17 years between 1987 and 2003 (Figure 4). Prior to 1987 mean daily stream flows of less than $90 \mathrm{cfs}$ were observed in only two of 14 years.

\section{Water Temperature}

Water temperature in Rock Creek near the mouth was monitored during a 3 year period, May - August, 1972-1974, by U. S. Forest Service (USFS). USGS monitored water temperature during a 3 year period, May - August, 1980-1982, and during a 7 year period, May - August, 1995 - 2001. Although not conclusive due to some data uncertainties, this monitoring suggests a warming trend in Rock Creek over the last three decades (Shane Hendrickson, USFS, 2003, personal communication). The means of daily maximum water temperatures from May through 



\section{ZUSGS}

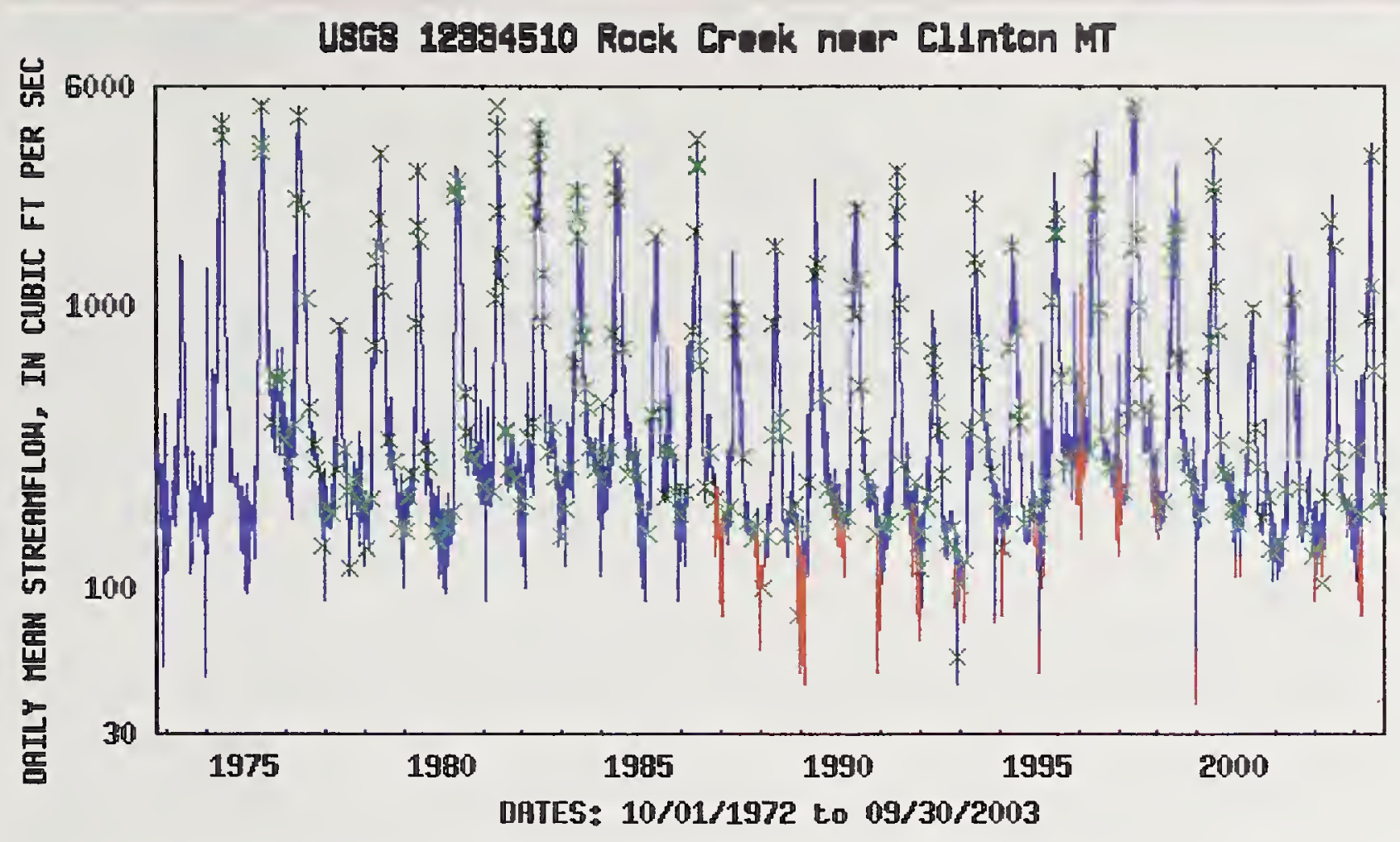

EXPLANATION

- DAILY MEAM STREAMFLOH $\times$ MEASURED STREAMFLOH ESTIMATED STREAMFLOM

Figure 4. Daily mean stream flow measured at the USGS gage station, lower Rock Creek, 10/01/1972 - 9/30/2003. 

August have increased from about 15.5 degrees C ( 60 degrees F) in 1972 to about 20 degrees C (68 degrees F) in 2001 (Figure 5). USFS regression analysis indicates this increase is statistically highly significant.

\section{Whirling Disease}

Sentinel cage studies of rainbow trout at thirty locations in the Rock Creek Drainage, 1998-2003, indicate whirling disease was present in the drainage at the onset of testing in 1998 (Bill Granath, University of Montana, 2004, personal communication). By 2003, caged rainbow tested positive for $M$. cerebralis, or whirling disease, at 24 of 30 , or 80 percent, of the study sites in the drainage (Figure 6). Only 6 of 30 sites tested negative ( $0 \%$ infection rates) for $\underline{M}$. cerebralis, including three test sites on the Upper Middle Fork of Rock Creek and one test site each on lower Spring, Ranch and Hogback Creeks.

In addition to being pervasive throughout the drainage, average grades of infection (AGI's) are disturbingly high, averaging 2.5 or higher in 82 percent of the sites tested in 2002, the most recent year for which full data analysis is available (Table 3). AGI's are based on the original MacConnell-Baldwin Scale of 0-4. At an AGI of 2.5 or higher significant adverse impacts on wild salmonid populations are likely to occur (Vincent, 2000).

Table 3. Average grades of infection of sentinel caged rainbow trout testing positive for whirling disease in 2002.

\begin{tabular}{|c|c|c|c|}
\hline $\begin{array}{c}\text { Average Grade } \\
\text { of Infection }\end{array}$ & No. of Sites & Percent of Sites & $\begin{array}{c}\text { Predicted Salmonid } \\
\text { Population Impact }\end{array}$ \\
\hline $0-1$ & 1 & $9 \%$ & None \\
\hline $1-2$ & 0 & 0 & Minor \\
\hline $2-2.5$ & 1 & $9 \%$ & Minor \\
\hline $2.5-3$ & 2 & $18 \%$ & Declines may occur \\
\hline $3-4$ & 7 & $64 \%$ & Declines will occur \\
\hline
\end{tabular}




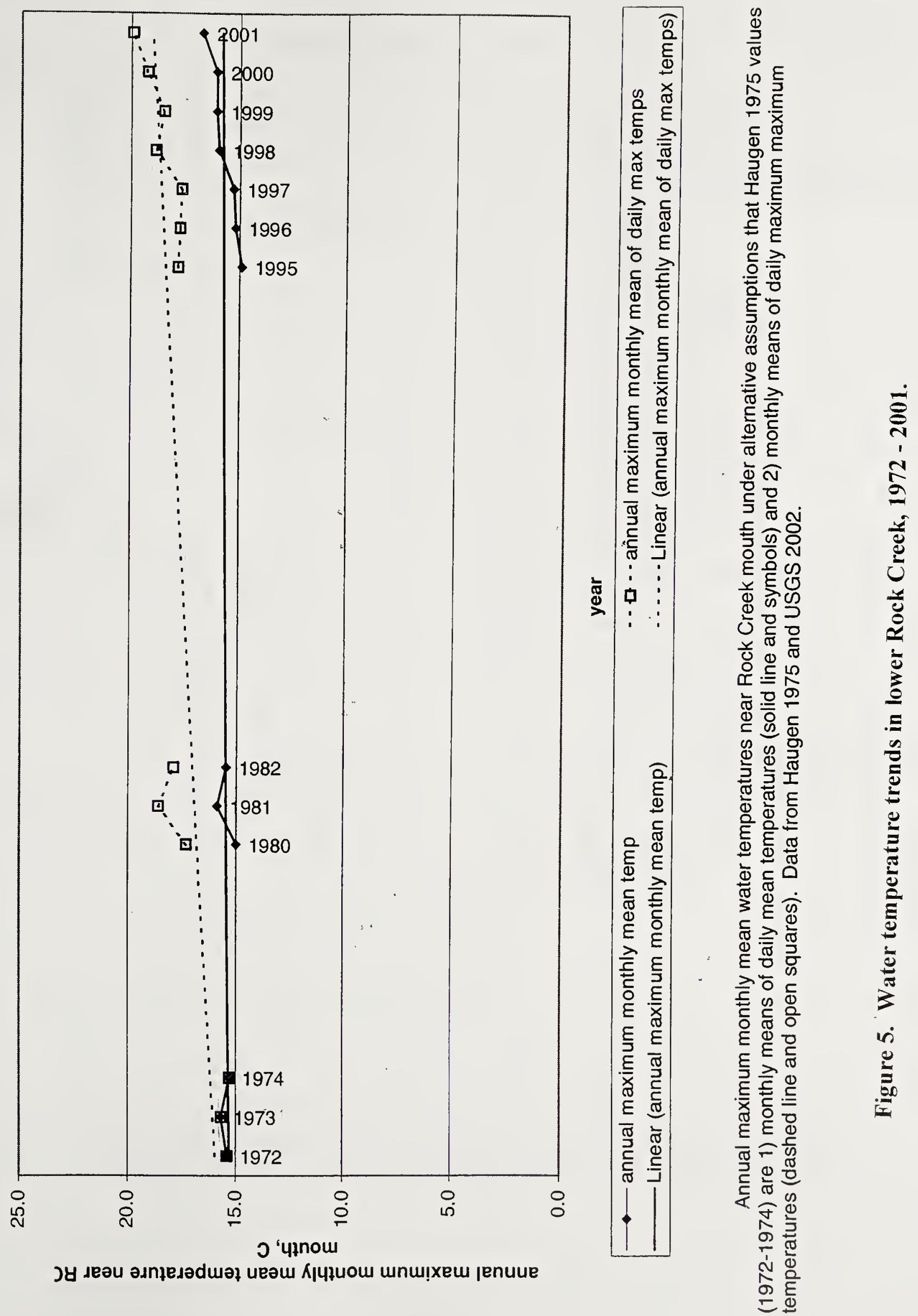



\section{Sentinel Cage Locations in the Rock Creek Drainage 1998-2003}

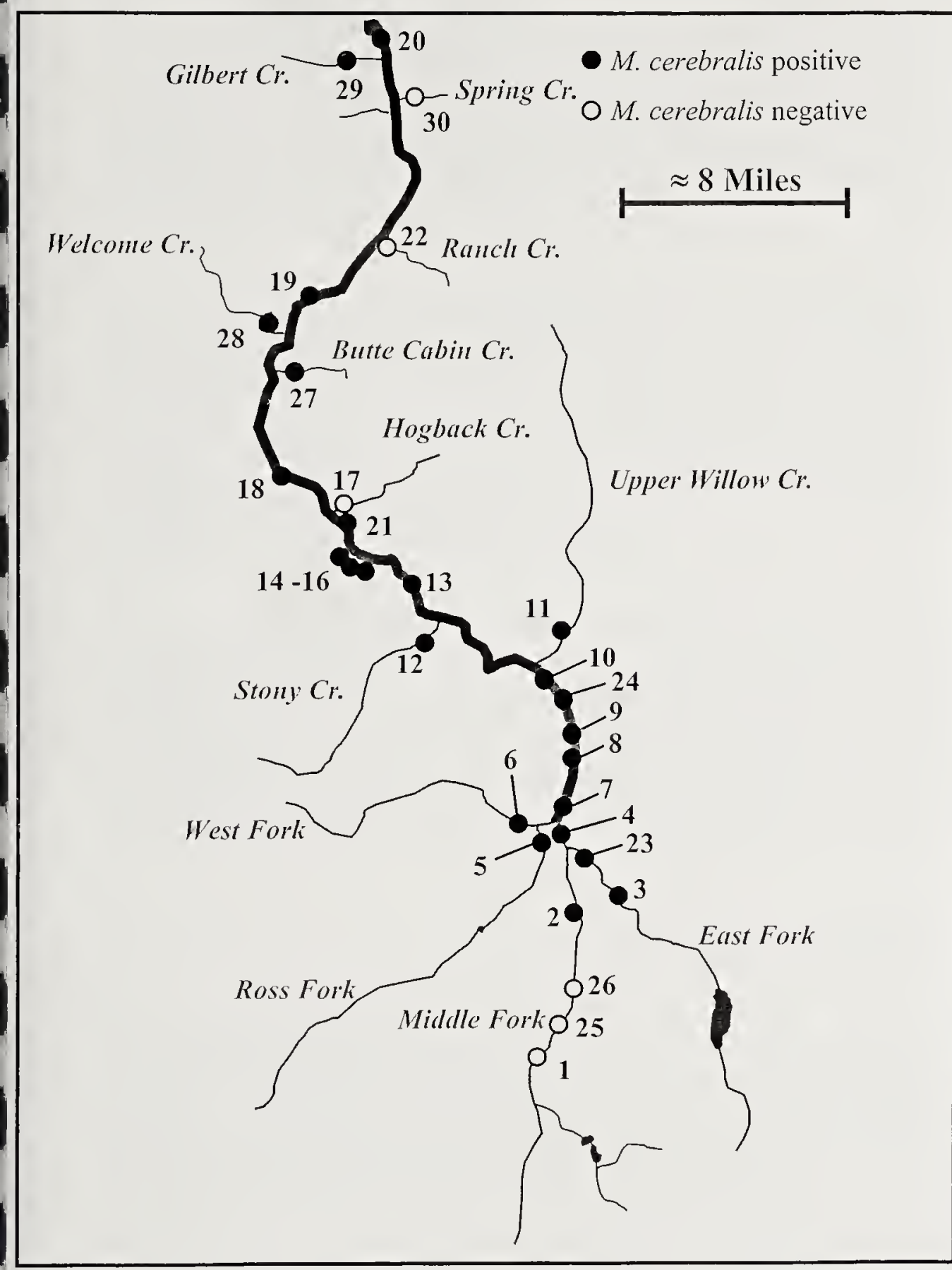

1 Upper Middle Fork

2 Lower Middle Fork

3 Upper East Fork (at bridge)

4 Lower East Fork (Upper Forks Bridge

5 Ross Fork

6 West Fork

7 Forks Bridge

8 Watson's Bridge

9 Bohrnsen's Bridge

10 Gillie's Bridge

11 Upper Willow Creek

12 Stony Creek

13 Windlass Bridge

14 Upper Puyear Ranch

15 Middle Puyear Ranch

16 Lower Puyear Ranch

17 Hogback Creek

18 Camp Siria (Hogback section)

19 Fish \& Game

20 Valley of the Moon

21 Above Hogback Creek

22 Ranch Creek

23 Middle East Fork (Beaver Dam)

24 Clark's Property

25 Middle Fork (Below Placer Creek)

26 Middle Fork USFS Bridge 5121

27 Butte Cabin Creek

28 Welcome Creek

29 Gilbert Creek

30 Spring Creek

Figure 6. Rainbow trout sentinel cage study locations in the Rock Creek drainage 1998 - 2003, depicting the locations testing positive for whirling disease. 



\section{CONCLUSIONS}

The spread of whirling disease has undoubtedly been enhanced by chronic drought and low stream flows in Rock Creek during the 17 year period from 1987 through 2003, and by the significant warming of water temperatures in Rock Creek observed between 1972 and 2001. Dramatic declines in catchable and large rainbow trout in the Fish and Game and Hogback Sections are attributable to this combination of low stream flows, higher water temperature and the spread of whirling disease.

Chronic drought and higher water temperatures have probably also been factors in the declines of westslope cutthroat trout and bull trout in Rock Creek. It appears the recovery of westslope cutthroat trout after restrictive regulations were implemented in May, 1979, was short lived. Westslope cutthroat trout peaked in density in fall, 1981, in the Fish and Game Section and in fall, 1982, in the Hogback Section and have generally declined or been unestimable since that time. Increased angling pressure since 1982 and the onset of whirling disease in the 1990's may also have affected westslope cutthroat.

Bull trout have not been estimable in the Fish and Game Section since 1986 and in the Hogback Section since 1993. Low flow and elevated water temperature have undoubtedly impaired bull trout. Bull trout are generally recognized as being more vulnerable to drought and increased water temperature than other trout species. Additional perspectives on the status of bull trout in the Rock Creek drainage are available through redd counts obtained in spawning areas. These findings are presented in the following section.

\section{Bull Trout Red Counts}

USFS biologists, Steve Gerdes and Shane Hendrickson, have spent considerable time and effort in locating and counting bull trout redds in the Rock Creek drainage. These efforts have helped to identify critical bull trout spawning areas in drainage. Since the counts have been made for an 11 year period from 1993 through 2003, they are also useful in helping to determine trends in bull trout status and abundance in the drainage.

In the Deer Lodge Forest segment of the drainage, redd surveys to date have identified six important bull trout spawning tributaries. These tributaries are Stony, Copper, Little Stony, Ross Fork, Carpp and Middle Fork Rock Creeks. Although redd counts have been variable from year to year, redd counts in Stony, Carpp, Copper and Middle Fork Rock Creeks have usually been relatively higher than redd counts in Little Stony and Ross Fork Creeks (Figure 7 and Appendix 1). Carpp and Copper Creeks are tributaries of Middle Fork Rock Creek while Little Stony Creek is a tributary of Stony Creek. This emphasizes the importance of the Stony Creek and Middle Fork Rock Creek drainages for bull trout spawning. Redd counts in Stony, Copper, Ross Fork, Carpp and Middle Fork Rock Creeks peaked in 1998 and have generally declined since then. Stream flow measurements in Middle Fork Rock Creek have declined by about a third since 1998, suggesting reduced redd counts may be correlated with reduced stream flow in the 



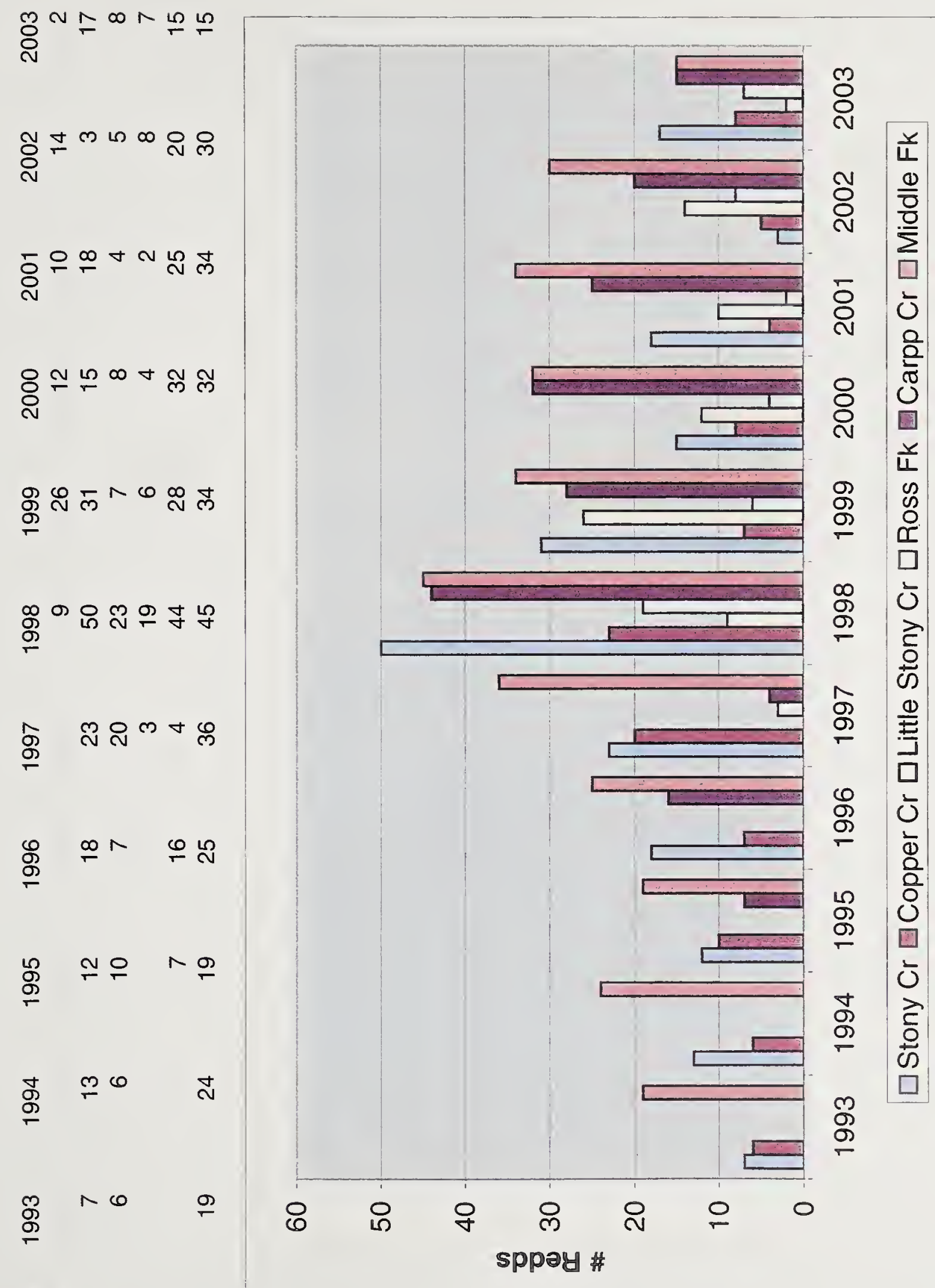





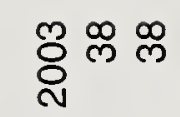

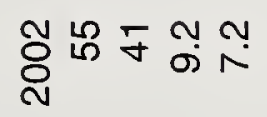

通

$\delta_{\text {웡웅 }}$

용요윰웅

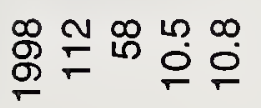

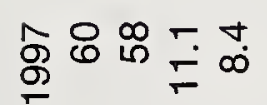

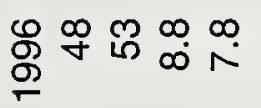

岗

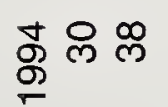

ᄍำ

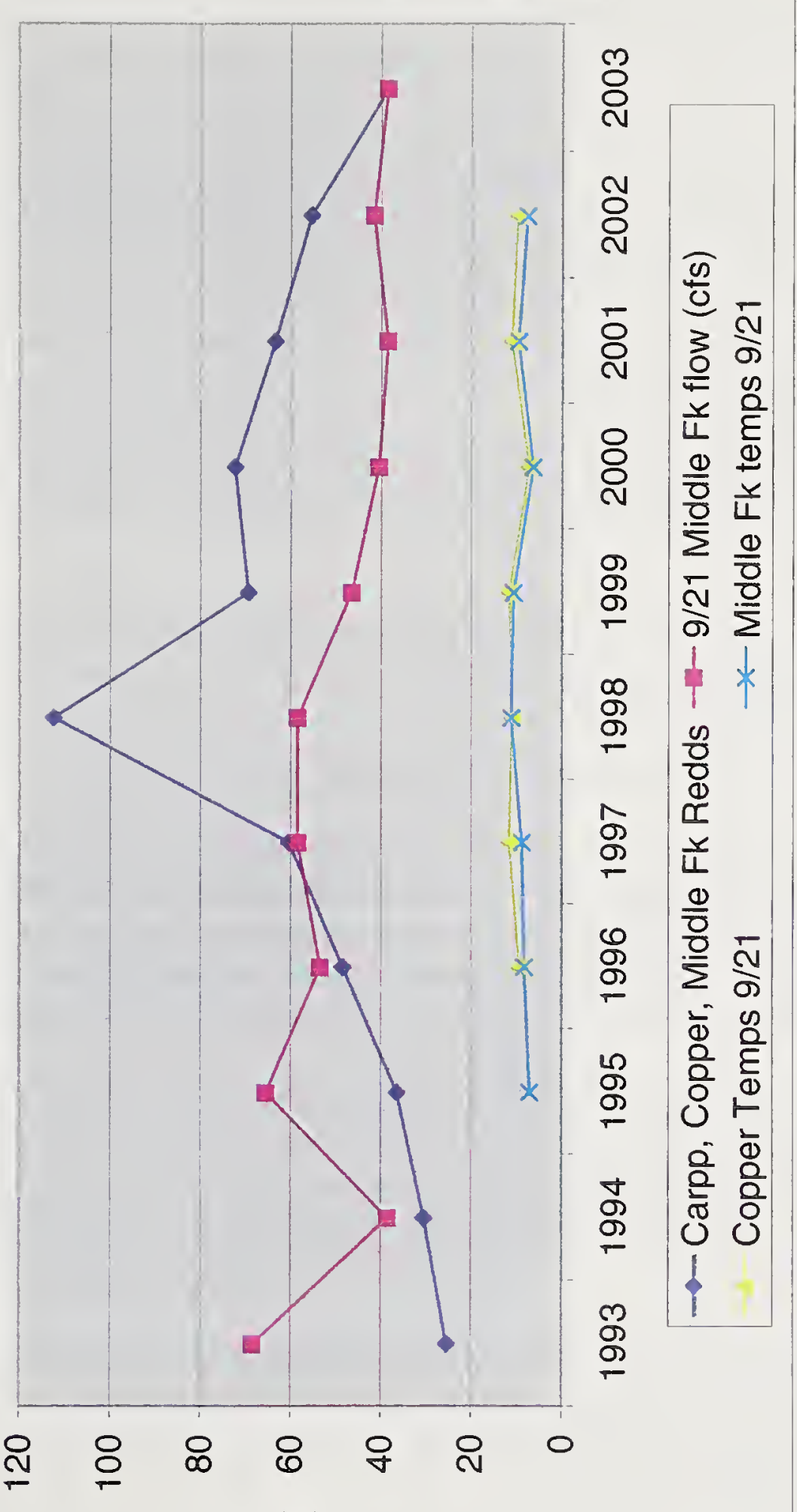

(כ)

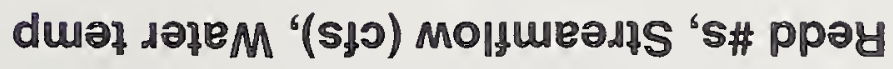

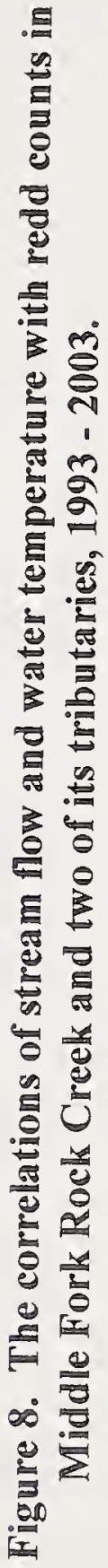

\section{융 를}

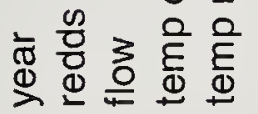



spawning tributaries (Figure 8).

\section{East Fork Rock Creek Reservoir Fishery survey}

East Fork Rock Creek Reservoir is the largest body of standing water in the Rock Creek drainage. An important adfluvial population of bull trout is found in the reservoir along with a few brook and rainbow trout.

Adfluvial bull trout survival is jeopardized in the reservoir due, in part, to aggradation of the stream bed upstream of the reservoir which historically has been used by bull trout for spawning. In addition, East Fork Reservoir is drawn down significantly each year during the irrigation season resulting in the movement of some fish through the dam outlet and into East Fork Rock Creek downstream of the reservoir. Since most of the water in the East Fork enters an irrigation diversion during the irrigation season, many bull trout are lost to the diversion. Ultimately, much of the water in the irrigation diversion is siphoned into an irrigation canal transferring water to the Flint Creek drainage. This results in the transfer of at least some bull trout from the Rock Creek drainage to the Flint Creek drainage where their fate is uncertain at best.

A fishery survey of East Fork Rock Creek Reservoir was made in 2003 to evaluate present day status of bull, brook and rainbow trout. Five overnight gill net sets were made each night from June 27 to July 1, 2003. The 25 total overnight gill net catch produced a total of 48 bull, 28 rainbow and 7 brook trout. No other game or nongame fish were captured.

Six of 15 mature female bull trout examined, or 40 percent, were reabsorbing eggs from the previous year, while forming new eggs in the abdominal cavity adjacent to the previous year's egg production. This finding confirms a high percentage of adfluvial bull trout in East Fork Reservoir are unable to successfully spawn. Poor spawning success and the loss of fish to the diversion ditch during the irrigation period have imperiled this bull trout population.

USFS intends to employ low tech habitat improvements in the East Fork of Rock Creek upstream of the reservoir in an attempt to restore some surface water for bull trout spawning (Steve Gerdes, USFS, 2004, personal communication). Since the bedload deposition is so extensive, its uncertain whether these improvements will be successful without physical removal or bypass of some of the bedload material.

The siphon in the irrigation canal downstream of East Fork Reservoir is in need of replacement. Fish screens at the water outlet works in the reservoir and screens at the diversion site downstream of the reservoir will be evaluated and probably employed as part of the siphon replacement funding to mitigate and minimize bull trout loss to irrigation diversion.

East Fork Rock Creek Reservoir was planted annually with hatchery rainbow trout for 47 years from 1938 through 1984. For the first 24 years from 1938 through 1961 the plant consisted of fingerling rainbow, one to six inches in length. For 23 years from 1962 through 1984 catchable rainbow, 7 to 10 inches in length were planted. The plant was discontinued after 1984 due to the 

assumption that too many fish were flushed from the reservoir during irrigation drawdown. However, this assumption was never validated by objective field observation.

Since rainbow trout still persist in the reservoir 20 years after planting ceased, it is clear some self sustaining natural reproduction of rainbow occurs. However, since rainbow and brook trout are scarce compared to bull trout, it is recommended that hatchery supplementation should be resumed to provide enhancement of angler catch and to reduce angling pressure on bull trout. Fingerling or catchable rainbow or cutthroat should be planted to evaluate escapement through the dam outlet works and to determine their relative value in improving the fishery. Once it is determined which species and size of fish are relatively less vulnerable to flushing, objective judgements can be made with regard to whether hatchery supplementation should be continued as a management tool.

Electrofishing studies should be conducted in East Fork Rock Creek upstream of the reservoir to evaluate the status of bull trout, and to determine whether rainbow, cutthroat or brook trout are present upstream of the reservoir. East Fork Rock Creek and East Fork Reservoir provide considerable opportunity for habitat and trout population improvement. 



\section{BIBLIOGRAPHY}

Vincent, E. R. 2000. Whirling disease report 1997-98. Montana FWP. 33 pp. 



\section{APPENDIX 1}

Bull Trout Redd Counts in Spawning Tributaries of Rock Creek

1993-2003 



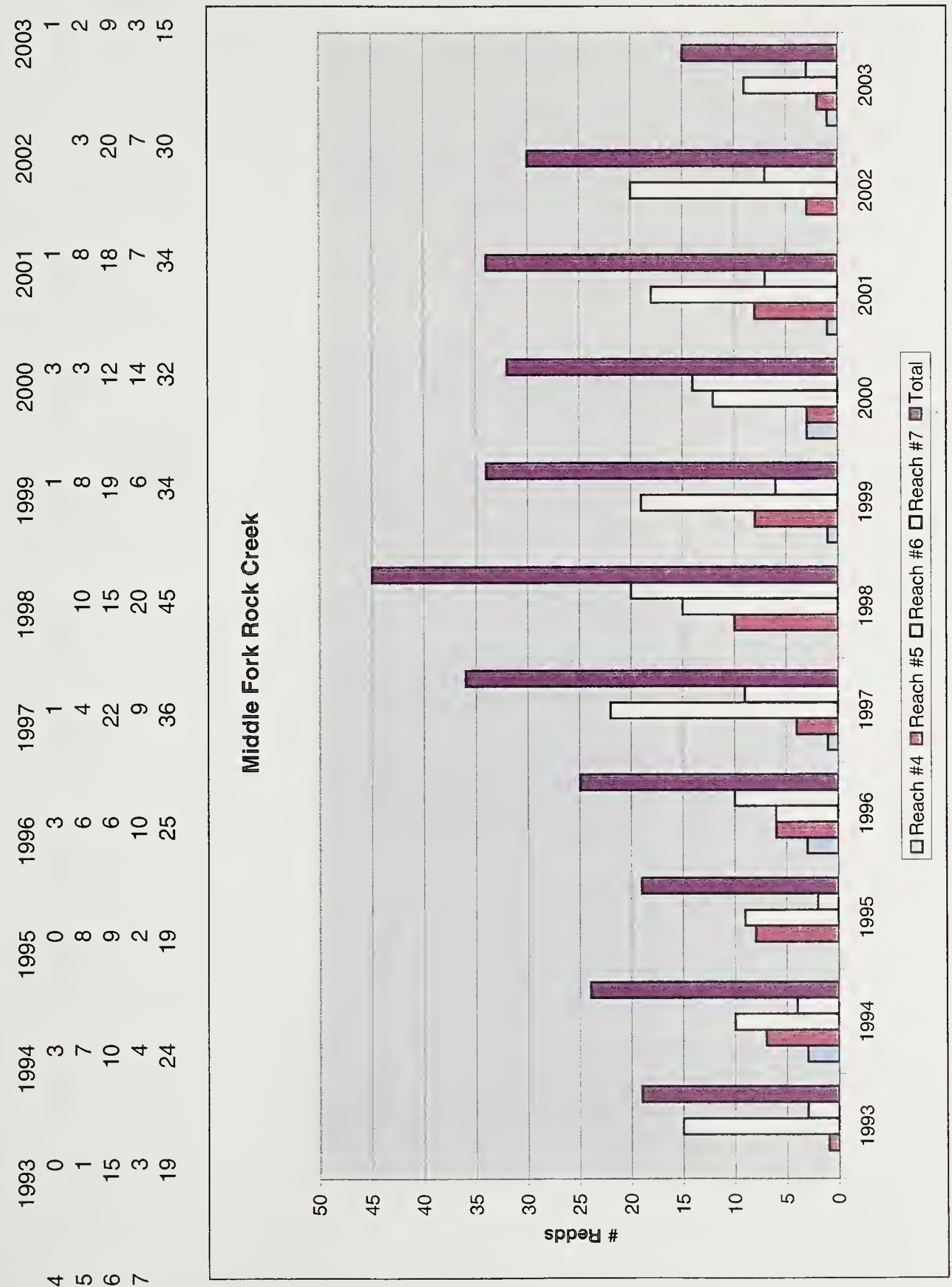

$\#$
$\frac{1}{0}$
$\mathbb{0}$
0
0 

용

No
ᄋ
$\overbrace{8}^{\circ}$

$8^{\infty}$

ब

$\frac{\infty}{\mathscr{N}}$

용

$\frac{6}{9}$

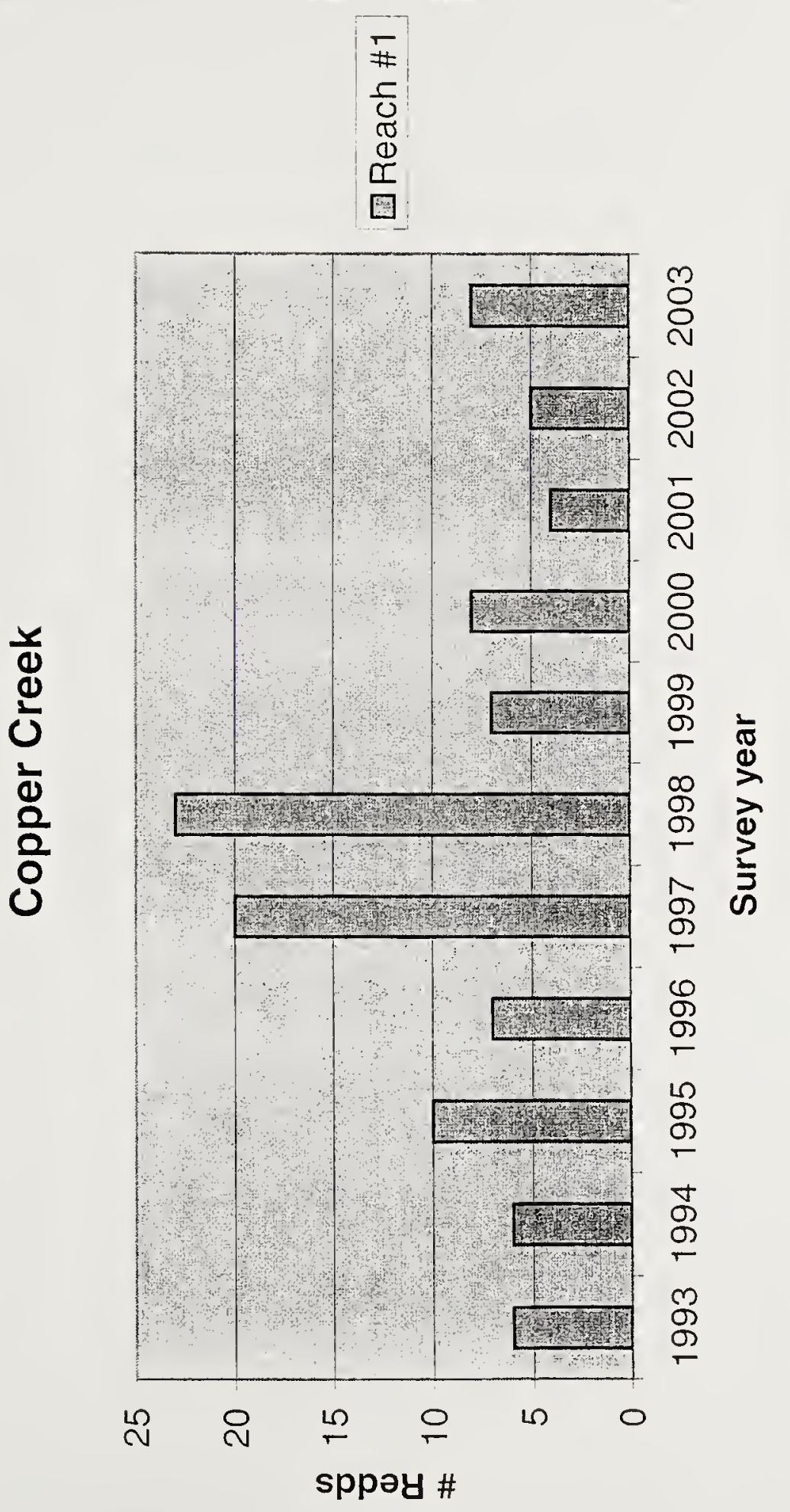

\#

동

용ำ

すั

क

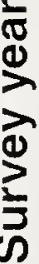





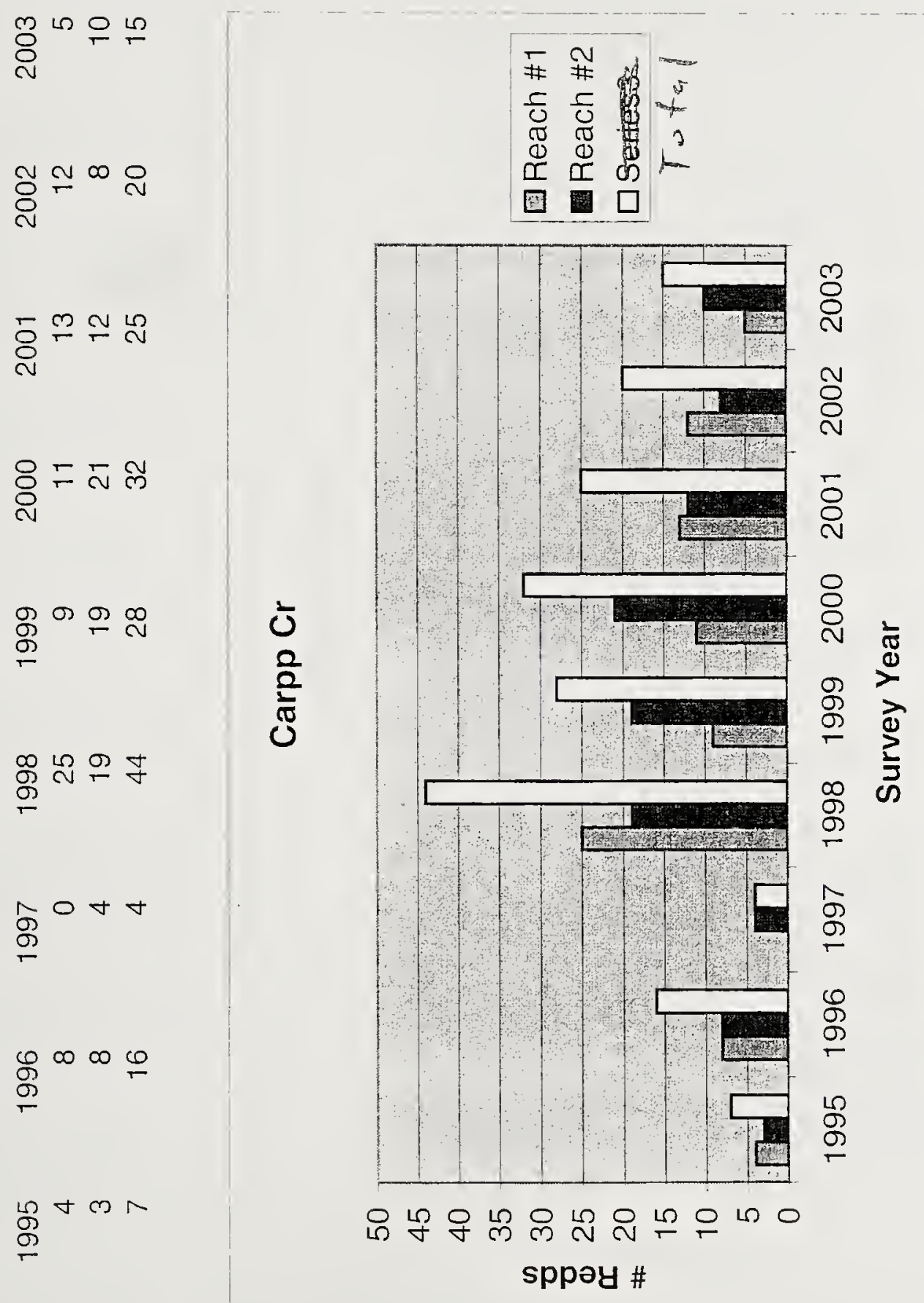

\#

듕

(I) 

尽 $N$

ญิ $-N m$

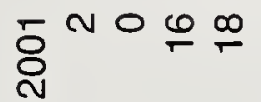

유

品 N

畧 ヘ

욤 m유

$\stackrel{\wp}{\stackrel{\circ}{\infty}} \stackrel{\infty}{+}$

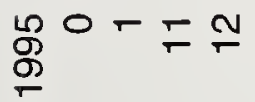

帝

$\frac{m}{g}-N+N$

TN

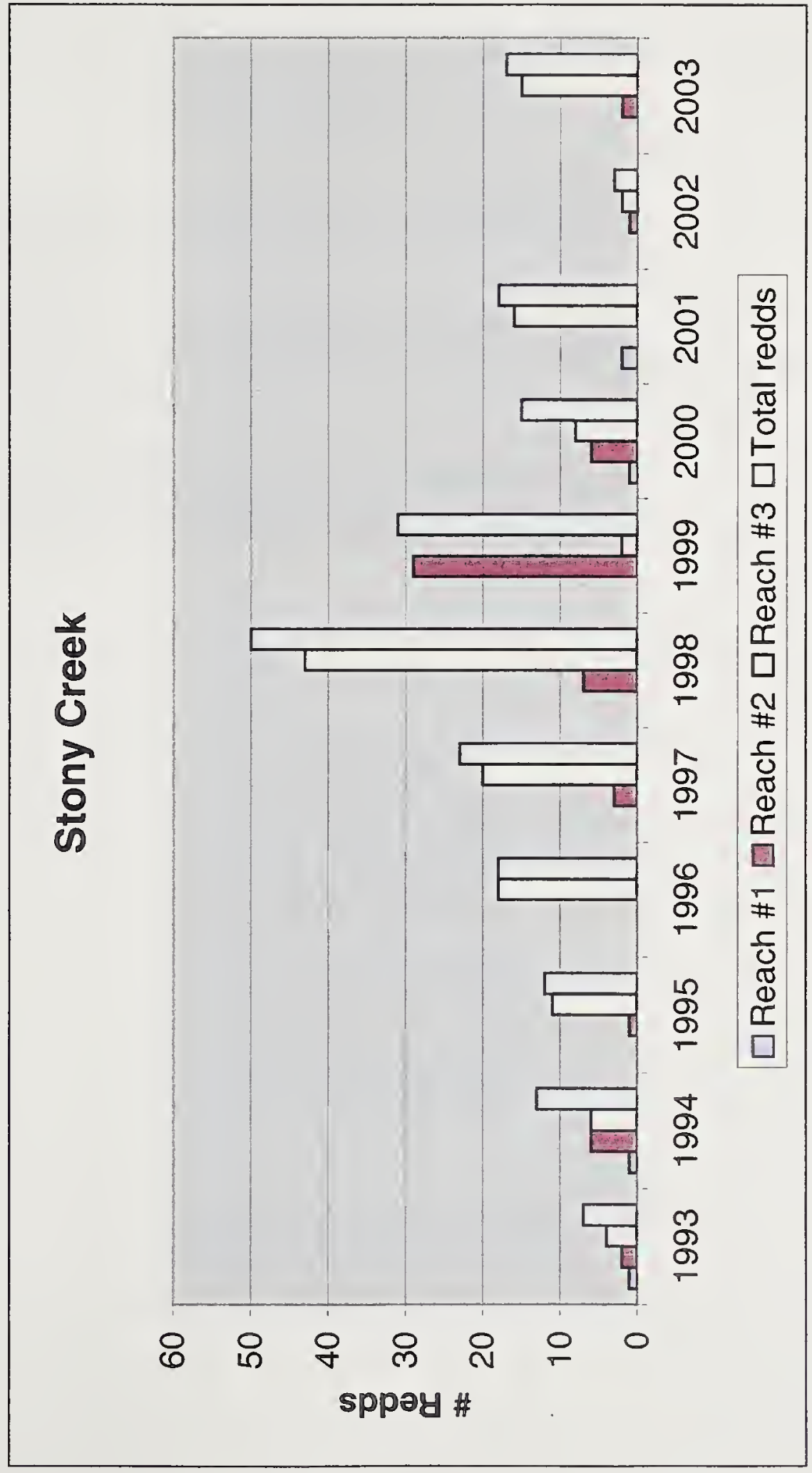

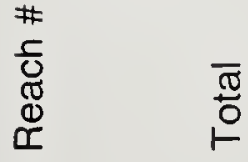





$\begin{array}{rrrrrrrr}\text { Reach \#5 } & 1997 & 1998 & 1999 & 2000 & 2001 & 2002 & 2003 \\ & 3 & 19 & 6 & 4 & 2 & 8 & 7\end{array}$

Ross Fork Rock $\mathrm{Cr}$

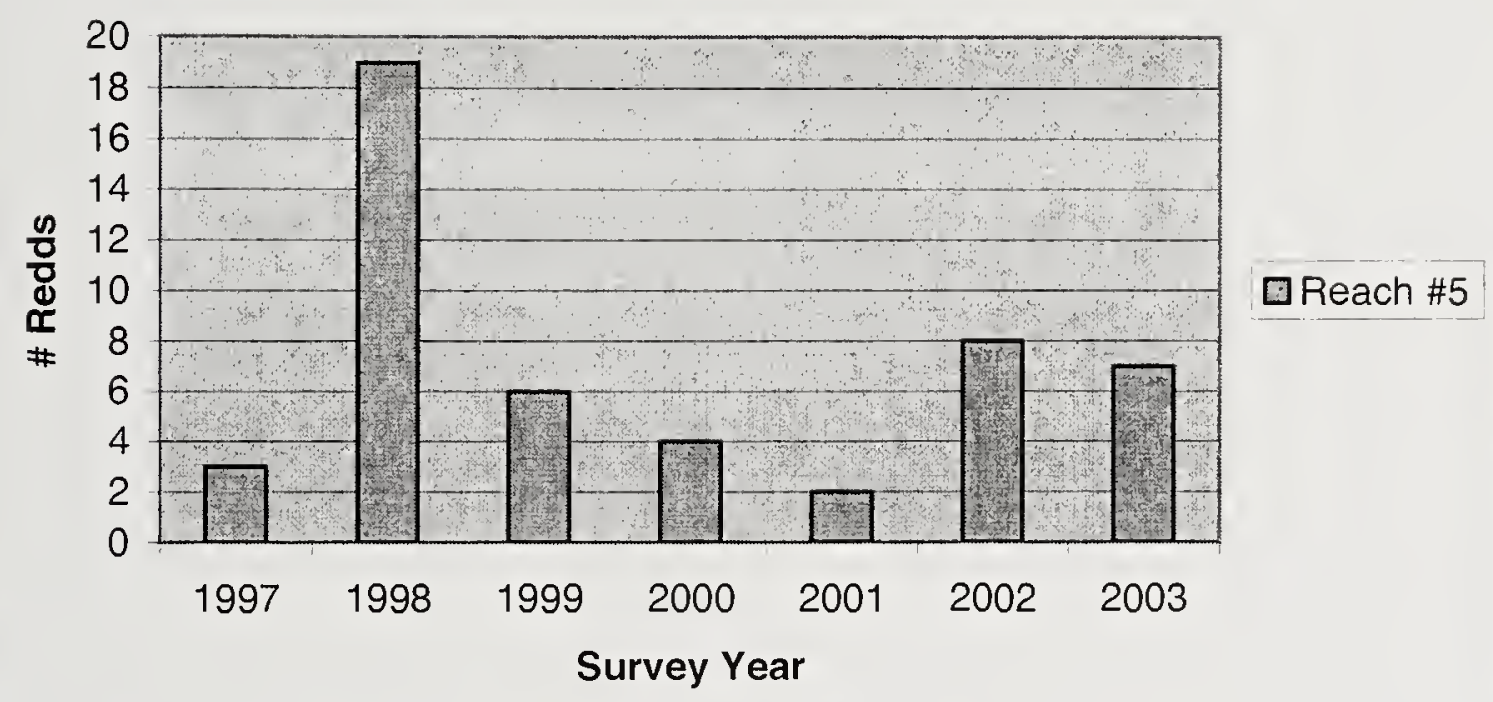






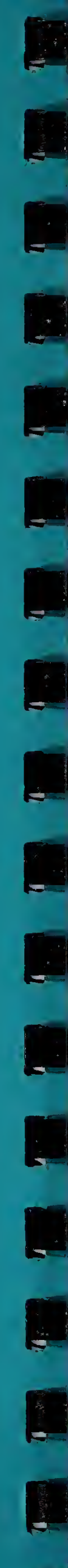

I

I 